\title{
Anita Desai's Fire on The Mountain: An Ecofeminist Reading
}

\author{
Maha Abdel Moneim Emara \\ Department of English Language and Literature \\ Faculty of Arts, Ain Shams University, Egypt
}

\begin{abstract}
Ecofeminism, as a social, political and philosophic movement, considers the oppression of women and the exploitation of nature as interconnected phenomena. This paper analyzes Anita Desai's Fire on The Mountain (1977) in the light of ecofeminist critical theories. The text explores how oppressive practices linked to patriarchal society operate forcefully on levels of gender and environment. It deploys a deft patterning of botanical, zoological, atmospheric and color imagery to convey the symbolic centrality of the narrative and the diverse analogies of the darker shades of nature and the darker aspects of femaleness.
\end{abstract}

Keywords: Ecofeminism, Anita Desai, Fire on The Mountain, symbolic images

I know I am made from this earth, as my mother's hands were made from this earth, as her dreams came from this earth ... you ... are earth too, and listen as we speak to each other of what we know: the light is in us. (Griffin, 1978, p. 227)

For years the link between the world of women and the natural environment has been central to the activity and thinking of ecofeminists. Works by ecofeminists like Susan Griffin (1976), Mary Daly (1978), Carolyn Merchant (1980), Ynestra King (1981), Ariel Salleh (1984), Karen Warren (1987, 1990), Val Plumwood (1993) and others stress the fact that ecology is a feminist issue. Nature is portrayed as a woman since its fundamental functions encompass reproduction and nurturing. Similarly women duties are envisioned as natural. As Rosemary Ruether (1975) believes women should be aware that there is no liberation for them nor any remedy to the ecological destruction in a society whose relationships are based on domination (Ruether, p. 204).

In fact, ecofeminism as a theory developed from various feminist activism: peace movements, labor movements, anti-nuclear, environmental, and animal liberation movements. Centered on the perceptions of ecology, feminism and socialism, ecofeminism's basic foundation as Greta Gaard (1993) explains, "is that the ideology which authorizes oppressions such as those based on race, class gender, sexuality, physical abilities and species is the same ideology which sanctions the oppression of nature"(p. 1). Ecofeminism describes the context that enables these forms of oppression as "an ideology whose fundamental self/other distinction is based on a sense of self that is separate, atomistic" (Gaard, p. 2).

This paper attempts an ecofeminist reading of this woman/nature interconnectedness in Anita Desai's (b.1937) Fire on The Mountain (1977) which won the National Academy of letters Award in 1977, the Sahitya Akademi Award in 1978. The novel depicts the darker shades of nature as connected to the darker aspects of the women concerned and their parallel domination and victimization. The text will analyze women's relationship to language and the numerous images that are rich in connotations. 
Ecofeminism, or ecological feminism, is a term coined in 1974 by Francois d'Eaubonne. It is a philosophy and movement that is born from the union of feminist and ecological thinking. In 1973, the Chipko movement emerged in defense of the Himalayan forests. In 1977, Wangari Maathai set up the reforestation projects in Kenya, the main aims of which were to promote a positive image of women and their independence. In 1980 Carolyn Merchant published her important work, The Death of Nature: Women, Ecology and Scientific Revolution where she traces the ancient links between women and nature bringing them to the foreground and showing how nature's ancient identity as a nourishing mother led to a connection between the history of women and that of nature.

In 1987, the American philosopher, Karen Warren wrote an influential article "Feminism and Ecology: Making Connections" in which she persuades feminists to turn their attention to ecological problems and to recognize the connection between environmental degradation, sexism and other forms of social oppression. Ecofeminism she asserts is a philosophical vision, an ethical trend as well as a political movement. In her book Ecological Feminism (1994), Warren adds that ecofeminism is also "cross-cultural" in that it encompasses "the inextricable interconnections among all social systems of domination, for instance, racism, classism, ageism, ethnocentrism, imperialism, colonialism, as well as sexism" (p. 2). Thus ecofeminism endeavors to show the parallel forms of domination, which reciprocally reinforce each other and lead to the degradation of life and the destruction of nature. Ecofeminists are significantly concerned with 'patriarchal conceptual frameworks' which are characterized by hierarchy and by conflicting dualism: male/female, mind/body, reason/emotion, universal/particular, culture/nature and where "the first term is associated with men and is elevated, the second is associated with women and is devalued" (Bianchi, 2012, p.8).

The Australian philosopher Val Plumwood focused on the nature of dualism in Feminism and The Mastery of Nature (1993). For her, dualism is linked to others forming oppressive connections bound and characterized by rejection and denial. Dualism is not just hierarchy but a way of thinking that makes equality and relationships unattainable. A dualism is a relationship of separation and dominion. Religion, philosophy, science, social models sexual standards education and economics reinforce this logic of dominion that assumes men's existence in the foreground and drives women into the background. Similarly, Peter Hay (2002) affirms that, "[p]atriarchy is a gender-privileging system of power relations... masculine values are regarded as 'species-defining', whilst the feminine is marginalized and trivialized. This has led to the categorization of women and values associated with the feminine as 'other'..." (pp. 73-74).

In fact, contemporary feminism has been deeply concerned with the dualisms of male/culture versus female/ nature. In The Second Sex (1974), Simone de Beauvoir formulates her famous passage on woman as the 'Other', which illuminates this very basic assumption about women. She believes that "[m]an seeks in woman the Other as Nature and his fellow being. But we know what ambivalent feelings Nature inspires in man. He exploits her, but she crushes him, he is born of her and dies in her; she is the source of his being and realm that he subjugates to his will" (pp. 62-63). De Beauvoir uses this identification to describe man's ambivalence toward woman and nature. This however becomes a crucial issue since man cannot clarify his relationship to both women and nature. A more recent ecofeminist like Maureen Devine (1992) believes that "woman is victim not only of individual men, but of patriarchal power structures ... that treat women and the environment as objects and within these power structures both become victims"(p. 52). According to ecofeminists the "other" includes not only women and nature but animals, people of colour, "Third world"people, the lower class, as well; 
in other words all the marginalized inferior categories (Gruen 1993, p. 80). Ecofeminists point to the linguistic links between oppression of women and land, such as the term "rape of land". Terms are used to express nature as feminine, such as the pronoun 'she' and term 'Mother Nature'. They also describe women as 'wild' and 'untamed' as nature.

In response to the parallel oppression of woman and nature, a variety of environmental movements recently emerged worldwide. One of these, which is relevant to this study, is the Chipko Tree movement of 1970s. In 1974, twenty seven women of Reni in northern India took simple but effective action to stop tree felling. They threatened to hug trees if the lumberjacks attempted to cut them down. The women's protest, known as the Chipko movement (chipko in Hindi means "to embrace" or "hug"), saved 12,000 square kilometers of sensitive watershed (Sheoran 388). The impact of environmental degradation is imperative on women due to her contiguous connection with nature. Thus as Bharatender Sheoran (2014) states, "ecofeminism in India has emerged as a vigorous movement parallelizing conservation of environment with improved living standards for women" (p. 388). Under the grab of development, nature has been exploited mercilessly and the feminine principle is no longer associated with activity, creativity and purity of life, but was considered passive and as a 'resource'.

The Chipko movement which is a grassroots, women-intiated, nonviolent protest movement, is not only about trees, but it is also about women-other human Others-nature interconnections. This is due to the fact that in India, forests are intimately connected to rural and household economies governed by women. Tree shortages in India pose significant problems for rural Indian women who are more dependent than men on tree and forest products and they are the primary sufferers of forest resource depletion. Vandana Shiva is the most important advocate of ecofeminism in India. In her book, Staying Alive: Women, Ecology and Development (1989), Shiva criticizes modern science and technology as a western, patriarchal and a colonial project which perpetuates violence against women and nature. Most ecofeminists and especially Shiva and Maria Mies held colonization as responsible not only for subjugating "third world" people but also for destroying and looting the natural resources which were until then held sacred and preserved by the "third world" society.

Capitalist patriarchy is another system that Mies and Shiva (2014) attack for changing the course of the lives of the "third world" people, animal and nature towards destruction. " Thus nature is subordinated to man, woman to man, consumption to production, and the local to the global and so on" (Mies and Shiva, 2014, p. 4). Though capitalist patriarchy brought the "third world" new ideas of development and progress, yet it is rightfully criticized for its skewed development that Mies and Shiva term as maledevelopment.

Other women-led movements in India have paved the way for several Indian women novelists to examine environmental issues and female subjectivity in literature showing a concern for the parallel oppression of both women and nature. The Indian women writers from the twentieth century onwards, whose literary works have advocated the concept of ecology in relation to woman, include Kamala Markandaya, Mahasweta Devi, Anita Desai, Shashi Deshpande, Usha K.R, Arunhati Roy and Kiran Desai.

Anita Desai is a famous Indian-English fiction writer who holds a peculiar stature among the contemporary Indian women novelists. As a writer, she has been nominated for the prestigious Booker Prize thrice and received a Sahitya Akademi Award in 1978 for her novel Fire on the Mountain (1999).*[note: Hereafter referred to as FOTM]. Most of her literary works explore the 
rebellion against patriarchal values that impose cultural ideologies to obstruct the way of the oppressed individuals to achieve their independence. The representation or symbolism of nature in relation to women characters in her works allows the reader to discern unfathomed spheres of the female ideology. The title of the novel is highly suggestive and symbolic. It indicates not only an actual occurrence happening now and then on top of the mountain, burning into ashes trees and houses, but also the raging passion within restless souls.

Fire on the Mountain orbits around three women characters Nanda Kaul, Raka and Ila Das, their interconnectedness with nature, their victimization and the equal oppression of nature. The novel depicts the darker shades of nature and highlights its alliance to the darker aspects of the women concerned. Thus, this novel makes it clear that ecological issues are connected to women, and non-human species. The three protagonists Desai created in her novel are trapped in dualistic patterns in which man symbolizes brutality, domination, fear and hate, arrogance and power, while woman and nature in every aspect of life are victims.

Fire on The Mountain exposes various forms of exploitation of both woman and nature. As regards the victimization of women, the narrative represents a discourse on violence that centers on the lives of the three women who are victims, either physically or mentally, of the patriarchal system. Nanda Kaul, a widowed great-grandmother, is a victim of her role as a dutiful wife to an unfaithful husband and as a mother to many children. Raka, her exclusive, withdrawn great-grandchild, is the victim of an abusive father. Ila Das, Nanda's childhood friend, unmarried, and the victim of her selfish brothers and her own reformist idealism. BR Nagpal (2014) states that:

The woman protagonists are portrayed as victims of an aberrant urban milieu, patriarchal family structures and bourgeoisie, bureaucratic, imperialistic, colonized, social scenario. It is in this context that the characters are in a state of revolt, despondency, morbidity and are driven to grapple with duality, fragmentation. ( $p .49)$

Fire on The Mountain tells the dramatic story of Nanda Kaul who after her husband's death retires in a cottage up the mountain at Carignano in Kasauli. There she creates a space of her own and embraces a life of solitude, privacy and confinement. Equipped with the bare necessities, accompanied only by Ram Lal, the cook, Nanda loves Carignano for its barrenness and isolation, its steep heights, scary ravines and slopes and becomes one with this desolate landscape. This reveals a kind of interconnectedness and what Irigaray considers as symbiosis, a basic form of relatedness between women and nature. This is because women's bodies especially in pregnancy are predisposed to be two in one and to host other bodies. Throughout all phases, the woman is either contained by or containing others.

Nanda lives out her old age in isolation in a Himalayan town Kasauli away from the world she knew as a wife and mother, not because of any religious or social responsibilities but "out of vengeance for a long life of duty and obligation" (FOTM, p. 30). Nanda perceives motherhood as a duty, a role enforced within a society which leaves her no choice since "the children [are] alien to her nature." Caring and nurturing are "a habit" and a "religious calling" which Nanda finds out to be "fake" for her and from which she now asks to be discharged. (FOTM, p. 30). In Desai's narrative, it is not clear whether Nanda Kaul belongs to the upper class or the middle class. She is like the other average Indian women who are always expected to be devoted, submissive and responsible traditional women.

The conventional ideology of Indian culture is that the women's position should be inferior compared to men. Women's physic and psyche are dominated by the institutions' societal structure. Thus, social value, religion, education and myth are used to repress the female 
through creating strong notions of hierarchy. Indian women become the victims of that process. They are compelled to be muted. Their voices do not get an opportunity to speak out their problems and needs. Whenever the woman is portrayed, she is in the second position below the man. She is always kept silent. Identifying this issue, Indian critic and feminist Gayatri Chakravorty Spivak (1985) asks-" can the subaltern speak?" To answer this question, she says: "There is no space from which the sexed subaltern subject can speak...The subaltern cannot speak" (p. 103).The reason, Spivak shows, is that Indian woman is always given a label of Sati or good wife. "Sati as a woman's proper name is in fairly widespread use in India...Naming a female infant 'a good wife' has its own proleptic irony...” (p. 102). While examining the power and position of Indian women.

Thus the position of the 'third world woman' is in-between 'patriarchy and imperialism. Nanda's chosen seclusion is actually nursing a deep wound in her heart, caused by her husband's unfaithfulness. She has selected this severance from all human relationships after passing through psychic suffering and bitter experiences of a hypocritical married life. Her husband does not respect her as a wife, rather he regards her as an excellent hostess of all parties he holds. Desai describes Nanda's trauma as thus:

The old house, the full house, of that period of her life when she was the vicechancellor's wife was the hub of a small but intense world, which had not pleased her. Its crowding had stifled her....They had so many children, they had gone to so many schools at different times of the day, and had so many tutors...all of different ages and families. (FOTM, pp. 29-30)

Externally everything appears smooth and pleasant but internally Nanda is burning with frustration and suppressed emotions.

The brutal death of Nanda's only friend Ila Das breaks the web of self-insulation that Nanda has been weaving since her arrival in Carignano. She feels guilty that, in protecting her solitude she has not asked her friend to stay the night. The police officer rings Nanda Kaul with a request to come to the police station to identify the body. Nanda is deeply shocked to hear the tragic news and suddenly lapses into reverie, into death. Wernmei Young Ade comments; "the phone call becomes a call to responsibility, specifically for [Nanda] part in the death of Ila"(p. 114). The narrative does not explicitly tell us that Nanda has killed herself, even it might strongly suggest so. "[s] he twisted her head, then hung it down, down, let it hang," and later, "Nanda Kaul on the stool with her head hanging, the black telephone hanging, the long wire dangling" (FOTM, p. 145). In fact, Nanda struggles with her inadequacy, incompleteness till the end of the novel.

Raka's arrival at Carignano is unwelcomed by Nanda who sees her arrival as an unwanted disruption of her peaceful retirement. Raka is the great-granddaughter of Nanda Kaul. Raka suffers the indifference of her parents. Tara, Raka's mother, suffers a chronic nervous breakdown that emanates from a marital disharmomy. Raka is sent to Carignano to recuperate from the after effects of typhoid. She is a sick fragile girl who avoids schooling and loves secrecy. Though a little girl, she can feel the indifference and callousness of her father, and its impact can be seen on her personality. In place of childhood joy, noise and activities, she decides to go to her great grand-mother's house in search for loneliness and solitude. Cruelties of her father towards her mother have always been alive in her memory. "If Nanda Kaul was a recluse out of a vengeance for a long life of duty and obligation, her great granddaughter was a recluse by nature, by instinct: she does not arrive at this condition by a long route of rejection 
and sacrifice, she was born to it simply" (FOTM, p. 48). She feels insecure and lonely and wishes to be left alone with nature. She is attracted to Kasauli because of its ravaged, destroyed and barren places. At Carignano, in the company of nature, there is no crying, no terror only peace in which one can hear the voice of silence. The uncivilized landscape of the mountain mirrors the damaged emotional landscape of her childhood. Raka is marginalized called "the crazy one," because of her attraction to "ravaged, destroyed and barren spaces" and because of her rejection of the supposedly civilized world "in which Raka had no part and to which she owed no attachment" (FOTM, p. 91). Raka, even as a child, recognizes the falsity of "civilized" society which tolerates and perpetuates her mother's mistreatment.

Raka's troubled familial experiences have turned her into a scary, hallucinating and agitated child. This is illustrated in her response to the party going on in the club. The drunken orgy in the club of the Research Station, which witnesses stealthily, serves to unlock her recollections of her own home, "her father,[coming] home from a party, stumbling and crashing through the curtains of night, his mouth opening to let out a flood of rotten stench, beating at her mother with hammers and fists of abuse-harsh, filthy abuse that made Raka cower under bedclothes and wet the mattress in fright"(FOTM , p. 71). She flees from there like a chased animal, her sweating fists beating her sides and her feet stamping on the thorns. Violence in the families could be traced to the patriarchal form of society. Men have an access to economic and social resources which endows them with greater power over women because women are economically and socially dependent. Violence is one of the ways in which men try to assert their strength and power.

Although Nanda and Raka refuse to be part of each other's life, yet they live in "double singleness" (Rogobete 2014, p. 97). Both of them love Carignano , both suffer from the same burden of traumatic memories and the same wish for solitude, however with different motivation, out of vengeance for Nanda, by instinct for Raka. Any attempt to bring them closer, including the trip together to the Monkey Point, fails. Nevertheless, eventually Daniela Rogobete (2014) speculates that "there is a strange reversal of roles since Raka's increasing independence and indifference towards her great grandmother ironically coincides with Nanda's increasing attraction to and dependence on her" (p. 97).

R. A. Singh (2009) states that "[i]n Raka, another kind of feminism is apparent which is more bold and aggressive"(p. 103). Eventually, Nanda discovers that Raka is "exactly like [her]"(FOTM, p. 64). In addition to her desire to be left alone, she is secretive and has a gift of disappearing. Raka appears to be a "freak". She spends her time gazing at a pine charred in the forest fire rather than the fresh leaves of the pine shining in the sun and smell its pleasant fragrance. In fact, Raka's weird interest in decay, destruction and decomposition, as Rogobete believes, "is translated in her frequent association with fire metaphors-symbol of inner trauma, desperate quest for self-assertion and independence" (p. 97). Raka finds refuge in Ram Lal the cook who wonders why she is not like the ordinary children who go to club and enjoy her time. She can be considered a representative of "radical feminism-energetic, bold and destructive of tradition"(Lal, p. 154 ). In fact, Nanda and Raka represent respectively the very old generation and the young generation of the Indian female world. While Nanda signifies the old female self of India, Raka represents the rebellious young generation of the Indian female world.

At the opposite end stands Ila Das, a lifelong friend and admirer of Nanda, relying upon her help and moral support, and an active fighter of women's rights within the community. Whereas Nanda is always associated with the firmness of tree and rocks and to the austerity of the Carignano landscape, Ila Das is described through her funny material belongings and her 
chaotic movements. Both Nanda and Ila Das are two different characters. While Nanda seems superior and aloof, Ila Das is fragile and intrusive. Yet at the end, "Nanda and Ila share the same vulnerability, hidden under the deceiving appearances of aloof isolation, or courageous social engagement"(Rogobete 2014, p. 95).

Ila Das struggles hard in her life to earn some money and later works as a welfare officer just for identity. She fights against child marriage by enlightening the people about the evils of this practice. However, a society rooted in patriarchal values, hinders and rejects her efforts. Talking to Nanda her friend, Ila says, "It's so much harder to teach a man anything, Nanda-the women are willing poor dears, to try and change their dreadful lives by an effort, but do you think their men will let them? Noooo, not one bit" (FOTM, p. 129). Misfortune strikes Ila Das when she is assaulted, raped and murdered by a man Preet Singh, a villager whom she stops from marrying his seven year old daughter to an old widower with six children, for a quarter of an acre land and two goats. The savage cruel Preet Singh leaves Ila Das in a miserable condition: "crushed back, crushed down into the earth, she lay raped, broken, still and finished" (FOTM, p. 143). Not only are the women looked down upon in her village, but also they are forced to watch their children die, because their men wanted them to listen to the village priest who tells them not to take their young ones to hospitals. The fate of Ila Das shows the ultimate destiny of a woman, which is sexual humiliation or death, if she goes against the patriarchal tradition. This indicates the transformation of the experience of Indian women. Aroop Saha (2011) believes that, " although the Indian women are surrounded by patriarchal ideology, a change has occurred in the construction of female subjectivity....Nanda Kaul's experience of suppressed rage and Ila Das' experience of violence, both physical and psychological, show an elevation to construct a female subject"(p. 238). Unfortunately, the formation of the female self cannot get the full face because of her inherited volatile present position and power which are not only fragmented but also distorted by male domination.

The extremity of Preet Singh's violence and hatred towards Ila is intensified by him wrapping the scarf "tighter, tighter, tighter," about her neck, and how he "tore at her clothes, tore them off her ... and raped her, pinned her down the dust and the goat droppings, and raped her"(FOTM , p. 143). In an interview with Ramesh Srivastava (1984), Desai says that Ila Das is based on a real person whom her mother knew and who occasionally visited their home in Delhi, and that she caused much hilarity and scorn among them. "Later when Anita Desai was in Kasauli, the lady had met with the violent death in a nearby village" (Srivastava, 1984, p. 211).

In her preface to Ecofeminism (2014), Shiva adds that violence against women is as old as patriarchy. Traditional patriarchy has structured the minds as well as the social and cultural worlds on the basis of domination over women and the denial of their full humanity and right to equality. Eventually it has taken on more brutal forms, like the murder of the Delhi gangrape victim and the suicide of the 17-year-old rape victim in Chandigarh and other cases (quoted in Mies \& Shiva 2014, p. xiv). Shiva goes further and adds that violence against women has taken on new and more vicious forms as traditional patriarchal structures have been "hybridized with the structures of capitalist patriarchy" (quoted in Mies \& Shiva 2014, p. xiv). As for the parallel exploitation of nature, from an ecofeminist perspective the rape of the earth and the rape of women are intimately linked-both metaphorically and materially as exemplified by, for example, National Commission on Women and the Research Foundation for Science, Technology and Ecology. 
The Pasteur Institute is a good example of the oppression and violence of non-human species. Normally one would associate it with humane studies, yet it stresses the abuse and exploitation of animals for purposes of research. "They have rabbits and guinea pigs there, too, many animals. They use them for tests.... They empty the bones and ashes of dead animals down into the ravine" (FOTM, p. 44). It is a good example of environmental speciesism which targets animals as Lori Gruen (1993) speculates that reducing animals to mere objects devoid of feelings, "is a common consequence of the scientific mindset by which those engaged in experimentation distance themselves from their subjects"(p. 66). Later when Raka sees the Institute, "[s]he shaded her eyes to look up at the swords of the Pasteur Institute chimneys...lashed about with black whips of smoke. Raka...smelt serum boiling,...choloroform and spirit, smelt dog's brains boiled in vats..."(FOTM, p. 49). Such an Institute is a strong representation of male's destructive scientific domination.

The forest fire is the best example of the cultivation of land which leads to the depletion of natural sources. This is a typical male capitalist ideology and a good example of environmental classism which usually targets the poor people. In Desai's narrative, poor people are greatly affected by fire. An old lady's house was burnt down in a terrible forest fire "she went mad and was put away". "Poor woman", Nanda wonders if she would have preferred to die in the fire (FOTM, p. 57). Modern technology which uses a beautiful wild area for an army camp proves the insensitivity of man towards nature and the patriarchal attitude in destroying the natural phenomena for economic purposes. In addition to the destruction of Kasauli landscape parallels the women's lives in Desai's narrative. Rape and murder of Il Das is parallel to the rape of the land, tourists industry as well as the army camp are responsible for the destruction of the land. Nanda Kaul bitterly says to Raka, "It really is saddening. One would have liked to keep it as it was, a--a haven, you know" (FOTM p, 57). Thus as has been shown, women's oppression and the exploitation of nature are two dimensions of many forms of injustice and discrimination; namely the victimization of women by men and the exploitation of the nonhuman world by man.

In the discourse of ecofeminism, the relation of woman to language focuses on the utilization of metaphor, and its function in describing the dualism of woman/nature on several levels, mainly the lexical, semantic, and narrative. It is noteworthy that dualism through language is suggestive of "phallologocentrism" and its emphasis on the domination of male culture. As defined by Jacques Derrida, "phallologocentrism" occupies a central place in theories of French feminism. Devine (1992) states that "language is power and meaning for many centuries women have been largely denied access to and use of public language, the language of dominant discourse. They have therefore been unable to influence it, make it responsive to them, or expressive of their needs" (93). In their concern with "phallologocenticism" as a system of signification, feminist critics show the damages it caused woman. They have prompted an emphasis on language as a space over which the male dominated phallologocentric discourse presided. According to Devine (1992), nineteenth and twentieth centuries " experienced renewed interests in language as a mirror of power and language as social behavior that communicates cultural values as well as defines and maintains social roles" (p. 94).

French feminist theorists, Irigaray and Cixous strongly believe that a woman must find a language system expressive of herself. Irigaray (1980) begins her essay, "When Our Lips Speak Together":

If we continue to speak this sameness, if we speak to each other as men have spoken for centuries, as they taught us to speak, we will fail each other... Absent from 
ourselves, we become machines that are spoken, machines that speak. Clean skins envelop us, but they are not our own. (p.69)

She expresses a sense of distrust in mainstream language. For women, it has been a vehicle of oppression; antagonistic to their sense of presence. Cixous in "The Laugh of the Medusa"(1976) exhorts woman to work out a new language wholly focused on female selfhood:

If woman has always functioned "within" the discourse of man, a signifier which annihilates its specific energy and diminishes or stifles its very different sounds, it is time for her to dislocate this "within", to explode it, turn it around, and seize it; to make it hers, containing it, taking it in her own mouth, biting that tongue with her very own teeth to invent for herself a language to get inside of. And you'll see with what ease she will spring forth from that "within". (p. 887)

Apparently both Irigaray and Cixous advocate a woman's language whose signifiers challenge the very concept of universality. Nevertheless, this idea of a special language for woman is very problematic in our context because of its dualistic implications. However, other feminist writers and theorists have spoken of this need and directed their attention to the lexical, for example, pronoun changes, renaming and redefining, narrative: woman as subject.

Ecofeminism is also a critique of metaphors which have associated woman and nature in dualistic opposition to man and culture, images of oppression and domination. Ecofeminism as discourse is interested in the processes by which woman and nature have been associated over the centuries. It undertakes to liberate both concepts from their connection with the duality of man and culture. In ecofeminist texts, the association of woman and nature is worked out through language. Ecofeminist experience underlines subjectivity and metaphor as major aspects that are central to re- consideration of woman and language in fiction; they provide endless possibilities in conceptualizing meaning and in the process, they undermine the power of phallohos (Devine 1992, p. 119).

C.G. Shyamala (2011) speculates that "Desai has the power to express sensibilities in her canvas using images from nature.... She is an artist who has the ability to carve such deep emotions within dexterous use of imagery that they announce the introduction of the explorations of the selves within the ecological framework" (p. 7). Desai's Fire on The Mountain skillfully exhibits numerous images rich in symbolic connotations. Plant and animal symbols are used to comment on the characters' personalities and their actions. Shyam Asnani (1981) remarks that "Desai is perhaps the only Indo-English novelist who lay stress on the landscape and correlates it with the psychic state of the protagonists" (p. 86). In Fire on The Mountain, however, the landscape is a foil for the inner psychic state. From the feminist perspective, the bleakness and barrenness of the landscape reflect Nanda's inner barrenness and solitude.

In fact, Carignano adequately fulfills Nanda's wish for solitude, stillness and silence. This wish is suggestively translated by the use of a rich animal, especially insect and bird, and plant symbolism. When drawing a portrait of Nanda, Desai focuses upon her composure and elegant posture, upon her eyes and facial expressions. From the very beginning, Nanda is associated with a pine tree connoting her wish for solitude up on the heights of the mountain. She wants to be rooted in a particular space with no other attachments or responsibilities. Though running from the past and building a new world of her own, Nanda still remains the prisoner of her painful memories, "She was grey, tall and thin in her silk sari made a sweeping, shivering 
sound and she fancied she could merge with the pine trees and be mistaken for one. To be a tree, no more and no less, was all she was prepared to undertake" (FOTM, p. 4). As a matter of fact, Nanda's sense of identification with the pine trees suggests "her desire for absolute stillness and withdrawal from life" (Indira 1994, p. 4). Nanda is like Carignano; stark, alone and barren. The quiet lonely house symbolizes the solitary life of Nanda. Shyamala remarks, "The barrenness and starkness associated with it symbolize an essential human conditionalienation" (p. 4).

Desai uses symbolic landscape descriptions that associate Nanda's past and destiny to the desolate remains of a formally active household on the mountain. Now old and abandoned, she represents an old world anchored into the past, unable to assimilate it and let go: "Shoals of rusted tins, bundles of stained newspaper, peels, rags and bones, all snuggling in grooves, hollows, cracks and sometimes spilling. Pine trees with charred trunks and contorted branches, striking melodramatic attitudes as on stage" (FOTM, p. 41). In describing Nanda's disappointment at Raka's arrival, Desai employs another botanical image. The image of the "yellow rose creeper" that "had blossomed so youthfully last month but was now reduced to an exhausted mass of grey creaks and groans again"(FOTM, p. 17) expresses the withering of Nanda's hope to maintain privacy and isolation.

The narrative is also full of numerous striking images of birds, insects and beasts that reflect Nanda's psychic states and moods and contribute significantly to the tone of the novel. Nanda seems to be caught between the eagle's aloofness and detachment. "She had wished, it occurred to her, to imitate that eagle-gliding with eyes closed" (FOTM 19). Nanda's wish for stability, suggested by the charred tree trunks, is contradicted by the image of the "white and yellow butterfly" (FOTM, p. 13) fluttering over her daughter's letter, hinting at the same time at the fragility of this self-created insulated universe and the inevitability of change as well as her wish for freedom.

Despite the fact that Raka signifies full moon, Nanda thinks the girl "looked like one of those dark crickets that leap up in fright but do not sing, or a mosquito, minute and fine, on thin precarious legs" (FOTM, p. 39). Furthermore, she does not welcome her arrival as a responsibility. As Raka slowly approaches her great- grandmother, she makes the "old lady feel more than ever her resemblance to an insect" (FOTM, p. 39). Raka's illness has proved detrimental and her great-grand mother is her only solace. Without any warmth or show of affection, Nanda welcomes Raka into her abode of isolation and introspection.

In fact, ecofeminist narrative employs images that contribute to a meaningful link between the various aspects of animate and inanimate relationships. Nanda and Raka perceive each other in symbolic terms. Raka sees Nanda as part of the barren landscape, "as another pine tree". Whereas for Nanda, Raka seems an "intruder, an outsider, a mosquito flown up from the plains" (FOTM, p. 40) ), a "newly caged" wild animal "newly tamed" (FOTM, p. 41), a "soundless moth"(FOTM, p. 46) and "a lizard like"(FOTM, p. 42 ) with "a gift for disappearing"(FOTM, p. 45). Raka is constantly described in terms of animal symbolism. Like a wild animal, Raka makes the gorges and hills, the cliff and ravines her home with such ease and naturalness that Nanda is finally forced to accept Raka as "the finished perfected model of what Nanda Kaul herself was merely a brave, flawed experiment" (FOTM, p. 47). She is a unique child who is totally disinterested in childish games and preoccupations, wild, independent and silent. Raka seems to be "a rabbit conjured up by a magician" (FOTM, p. 47). Though there seems to be no place for magic and fairytale in her life, she is but a "bird fallen out of its nest, a nest fallen out of a tree" (FOTM, p. 50). 
Although the novel is laid in the quiet seclusion of Kasauli, Desai skillfully uses various sound images to create a tonal contrast that intensifies the mood of the novel. Desai writes; "Flies, too lazy for flight, were caught in...midday web and buzzed languorously.... Inside, the flies. Outside, the cicadas. Everything hummed, shrilled, buzzed and fiddled"(FOTM, p. 22). As soon as Raka arrives at Carignano, she listens "to the wind in the pines and cicadas all shrilling incessantly in the sun with her unfortunately large and protruding ears, and thought she had never before heard the voice of silence" (FOTM, p. 40). Nanda's mind is filled with thoughts about freedom, she hears "A burst of crackling and hissing, as of suddenly awakened geese, a brief silence, then a voice issued from it that made her gasp and shrivel" (FOTM, p. 22). It was the voice of her friend Ila Das who wanted to spend some time with her friend Nanda. As Nanda talks to Ila over the phone, she watches "The white hen drag out a worm inch by resisting inch from the ground till it snapped in two. She felt like the worm herself, she winced at its mutilation" (FOTM, p. 21). Nanda feels she is being persecuted like the worm in her desperate attempt to escape Ila; "still staring at the hen which was greedily gulping down bits of worm, she thought of her husband's face and the way he would plait his fingers across his stomach" (FOTM, p. 22). This prey-predator image of hen pecking at a worm is a cruel reminder of her past suffering at the hands of the adulterous husband and her present awareness about the harsh realities of life.

Though Nanda is determined to remain unaffected by the happenings outside, she cannot help but listen to the quarrel of the monkeys and the shrill voices of the parrots. As Nanda decides to take a walk on the lawn, she spots a lapwing that gets agitated on her unexpected arrival. Nanda thinks that "hunted, fearful bird, distracting and disturbing" (FOTM, p. 26). Nanda is compared to a bird that has been aroused from its serenity at the arrival of Raka and Ila Das. Throughout the work we hear the rustling and fluttering of leaves and twigs, flowers and wings and the characteristic chirps and cries of birds and animals.

The moon is a metaphor of Raka, herself, as well as it stands for the lunacy and madness which draws out the violence to come. The cuckoos which are first seen as domesticated birds in the eyes of Nanda, evolve into the "demented birds that raved and beckoned Raka on to a land where there was no sound, only silence, no light, only shade, and skeletons"(FOTM, p. 90). According to NR Gopal "[Fire on the Mountain is] the only novel ... in which nature plays such a vital role on the level of symbolism and imagery and it has to be accepted that she [Desai] makes effective use of this technique to portray different characters"(p. 85). Imagery and symbolism that are used in the Desai's narrative are so effective that critics incline to associate them with what is occurring in the world. In her struggle to remain detached, she virtually links the outside with the inside as the imagery of the bird shows; "that hunted, fearful bird, distracted and disturbing" (FOTM, p. 26).

The image of the fire is also suggestive. Not only does it refer to a natural phenomenon in the mountains due to summer heat and dryness but it has also a symbolic meaning that connects Nanda Kaul and Raka. One night they witnessed a forest fire together, for Nanda, the forest fire regularly occurs, but to the young, it fascinates her. She imagines that "she heard the cries of animals and birds burning in that fire" (FOTM, p. 75). The forest fire, however, is endowed with "[a] quality of a dream-disaster, dream-spectres that follow one, trap one"(FOTM, p. 76). RS Shamara (1981) reads the fire as "expressive of Raka's resolve to destroy a world where a woman cannot hope to be happy without being unnatural."(p. 145). It appears unreal and in its unreality, it foretells a disaster. R. A. Singh (2009) believes that the title of the novel Fire on The Mountain implies a sense of irony since mountains are "usually havens, calm places, 
associated with holiness and divinity" (p. 110). Its humans who disrupt the 'calm' and 'holiness' of their havens.

In fact the mountain symbolizes Nanda and the fire is symbolic of Raka's wild nature. The rape and brutal murder of Ila Das in the forest in the dark raises a frightening awareness of male dual domination of both women and nature.

At the end of the novel, the mischievous girl, Raka, actually sets fire: "Look, Nani, I have set the forest on fire. Look, Nani-Look-the forest is on fire" (FOTM, p. 145). This is followed by the authorial statement: "Down in the ravine, the flames spat and crackled around the dry wood and through the dry grass, and black smoke spiraled up over the mountain"(FOTM, p. 146). The fictive world of Nanda is totally shattered by the news of Ila Das's rape and murder. Against this backdrop, the utterance of Raka, "Look Nani, I have set the forest on fire" (FOTM, p. 146) attains a great symbolic significance. It is described by R. S. Sharma as, "expressive of Raka's resolve to destroy a world where a woman cannot hope to be happy without being unnatural" (p. 127).

To conclude, ecofeminism as an ideology and movement finds that the oppression of women is interlinked to the oppression of nature with the same masculine attitudes. Anita Desai's Fire on the Mountain (1977) depicts gradual destruction of the ecosystem of the Kasauli hills and its eventual destruction by the devastating forest fire. The characterization in the novel also echoes this gradual desiccation. The response of the female characters to life has been externalized with natural images to proliferate their inner consciousness. Desai's characters carry on a dual life; the inner and the outer. The three protagonists are trapped in dualistic pattern in which man symbolizes brutality, dominance and violence. In fact, Fire on the Mountain addresses and unfolds an amazing variety of issues; motherhood, femininity, isolation, death, exile, violence, patriarchal domination and exploitation of nature. It also embodies dualistic issues; nature versus civilization, wilderness versus domesticity and free will versus fate. The novel is rich with images that reinforce woman-nature interconnectedness.

\section{References}

Asnani, S. (1981). Theme of Withdrawal and Loneliness in Anita Desai's Fire on the mountain. Journal of Indian Writings in English, 9 (1), 81-92.

Bianchi, B. (2012). Introduction. Ecofeminism: The Ideas, The Debates, the Prospects. DEP, no. 20. 1-25

Cixous, H. (1976). The laugh of the Medusa: Viewpoint. (K. Cohen \& P. Cohen. Trans.). Signs,1 (4), $875-893$.

De Beauvoir, S. (1974). The second sex. (H.M. Parshley. Trans. \& Ed.). New York: Vintage Books.

Desai, A. (1977). Fire on the mountain. London: Vintage.

Devine, M. (1992). Woman and nature: Literary reconceptualizations . London: Scarecrow Press.

Gaard, G. (Ed.) (1993). Ecofeminism: Women, animals, nature. Philadelphia: Temple University Press.

Gopal, N. R. (1999). A critical study of the novels of Anita Desai. New Delhi: Atlantic.

Griffin, S. (1978). Woman and nature: Roaring inside her. San Francisco: Harper \& Row.

Gruen, L. (1993). Dismantling oppression: An analysis of the connection between women and animals. In G. Gaard (Ed.). Ecofeminism: women, animals, nature. Philadelphia: Temple University Press.

Hay, P. (2002). Main currents in western environmental thought. Australia: University of New South Wales Press. Indira, S. (1994). Anita Desai as an artist. New Delhi: Sterling. 
Irigaray, L. (1980). When our lips speak together. (C. Burke Trans.). Signs, 6 (1), 69-79.

Lal, M. (1984). Anita Desai: Fire on the mountain. Major Indian novel- An evaluation. N.S Pradhan (Ed.). New Delhi: Arnold Heinemann.

Mies, M. \& Shiva, V (2014). Ecofeminism. London: Zed Books.

Nagpal, B. R. (2014). Existential- spiritual quest in Anita Desai's Fire on the mountain. In A.N. Dwivedi (Ed.). Anita Desai's The Fire on the Mountain. India andUSA :Roman Books, 49-60.

Plumwood, V. (1993). Feminism and the mastery of nature. London: Routledge,

Ruether, R. (1975). New woman, new earth: Sexist ideologies and human liberation. New York: Seabury Press.

Rogobete, D. ( 2014). Three facets of Indian womanhood in Anita Desai's Fire on the mountain. In A. Dwivedi .Ed.

Roman critical contexts: Anita Desai's the fire on the mountain. India and USA: Roman Books, 89-102.

Saha, A. (2011). Portrayal of psychic violence in Fire on the mountain and Bluest eye. Stamford Journal of English,

6, 230-248. DOI: 10.3329/sje.v6.0.13916

Sharma, R. S. (1981). Anita Desai. New Delhi: Arnold-Heinmann.

Sheoran, B. (2014). Discourses of feminist environmentalism (ecofeminism) in fictional writings of contemporary Indian women novelists. An International Refereed e-Journal of Literary Explorations, 2 (1), 386-391.

Shiva, V. (1989). Staying alive: Women, ecology and development. London: Zed.

Singh, R.A. (2009). Three novels of Anita Desai: A critical spectrum. Delhi: Roshan OffsetPrinters.

Spivak, G. C. Can the subaltern speak? www.sfu. Ca/iirp/documents Spivak \% 201988.

Srivastava, R. K. (Ed.) (1984). Perspectives on Anita Desai. Gaziabad: Vimal Prakashan.

Shyamala, C.G. (2011). Nature and Ecocriticism in Cry, The peacock and Fire on the mountain. The Criterion: An International Journal in English. 2 (3), 1-9.

Warren, K. J. (Ed) (1984). Ecological feminism. London: Routledge. 